\title{
Fractions of heavy metals in the soil of the urban agglomeration with increased traffic
}

\author{
Monika Łukawska ${ }^{1}$, Małgorzata Widłak ${ }^{2,}$, and Agata Widłak $^{2}$ \\ ${ }^{1}$ Kielce University of Technology, Faculty of Construction and Architecture, \\ ${ }^{2}$ Kielce University of Technology, Faculty of Environmental, Geomatic and Energy Engineering, \\ Department of Water Supply and Sewage Technology, al. Tysiąclecia Państwa Polskiego 7, \\ 25-314 Kielce, Poland
}

\begin{abstract}
The paper presents the results of research on the content of selected heavy metals $(\mathrm{Cu}, \mathrm{Pb}, \mathrm{Zn}, \mathrm{Ni})$ depending on $\mathrm{pH}$, organic carbon content and soil sorption in the direct location of busy streets around the campus of the Kielce University of Technology. Based on the conducted studies of the sequential fractionation of metals by the BCR method was found that the highest content of nickel fraction FI (exchangeable) was $142.75 \mathrm{mg} / \mathrm{kg}$. However, the total nickel concentration in all research areas exceeded the value specified in the Journal of Laws approx. 2 times. The lowest content from the analyzed metals in the surface layer of soil was found for zinc, the content of which was $1.5 \%$ in relation to the standard. The average percentage share of the analyzed metals in the separated fractions, in relation to the total content, was in decreasing series for Ni: FIII $>$ FI $>$ FII $>$ FIV; for $\mathrm{Pb}$ : FII $>$ FI $>$ FIV $>$ FIII; for $\mathrm{Cu}$ : FII $>$ FI $>$ FIII $>$ FIV and for Zn: FII $>$ FIII $>$ FI $>$ FIV. The studied soils are characterized by a varied granulometric composition of sand fraction, from very thick $(1000 \mu \mathrm{m}-2000 \mu \mathrm{m})$ to very fine $2 \mu \mathrm{m}-50 \mu \mathrm{m})$. Statistical calculations showed that the $\mathrm{pH}, \mathrm{C}_{\text {org }}$ content and sorptivity of the studied soil correlate with each other.
\end{abstract}

\section{Introduction}

The problem of soil pollution is very important due to the possibility of indirect or direct negative impact on human health. Heavy metal contamination is particularly dangerous as a result of migration and accumulation. The physicochemical properties of soils influence the absorption of elements by plants and their inclusion in the trophic chain system [1]. The transition of elements to subsequent links in the food chain and consequently to the human body can cause immediate acute poisoning or chronic conditions. Chronic diseases may occur for a long time in latent form. After some time, they can cause very dangerous mutagenic changes or damages to the central nervous system $[2]$.

\footnotetext{
* Corresponding author: mwidlak@tu.kielce.pl
} 
Soils contamination in the direct impact of road communication routes is caused by organic compounds formed with incomplete combustion of fuels, organic and mineral compounds found in fuels and lubricants, heavy metals included in fuel additives, salt used to remove icing [3]. Dust from automotive sources containing particles of abrasive materials consumable during vehicle operation. The content of heavy metals in the soil is to a large extent related to the distance from roads, traffic volume, terrain, as well as the way of use. The width of the impact zone covers a distance of up to $150 \mathrm{~m}$ from the roadway. One of the ways to protect against the negative impact of increased traffic is by planting roadside vegetation. It constitutes a protective barrier against vehicle exhaust gases, which by entering the atmosphere, also affect the soil environment pollution [4]. The way of binding heavy metals, and thus their bioavailability depends on many soil properties.

Due to the degree of risk, heavy metals $\mathrm{Cd}, \mathrm{Hg}, \mathrm{Pb}, \mathrm{Cu}, \mathrm{Zn}$ are included in the group of very high risk; $\mathrm{Mo}, \mathrm{Mn}, \mathrm{Fe}$ of high risk; Ni, Co of medium risk and $\mathrm{Sr}, \mathrm{Zr}$ of low risk [5]. The natural content of metals in the soil depends on the type of parent rock, granulometric composition, organic matter, sorptivity and soil $\mathrm{pH}$. An important source of pollution with nickel, copper and lead is their emission to the atmosphere with products of combustion of liquid fuels in car engines near communication terraces [6].

The aim of the conducted studies was to determine the impact of pollution caused by increased road traffic on the physicochemical properties of the campus soils of the Kielce University of Technology. Campus areas are used to conduct student field studies and for recreation by students and residents of nearby settlements.

Such research was carried out for the first time.

\section{Materials and methods}

The study covered the soil on busy transport routes around the campus of the Kielce University of Technology, which covers an area of 22 hectares. Green areas have been recultivated after the development of the campus, but about the areas in surrounding blocks of neighboring housing estates take care their residents (Table 1). Test samples were taken from the humus level up to $30 \mathrm{~cm}$ in autumn and spring, when teaching sessions are taking place at the university. It is very important to protect the area from the effects of contamination with substances coming from the automotive industry, which can enter the body through inhalation rout, due to field activities of students (point 3) (Table 1, Fig. 5). The analyzed soil samples were mixed. By each point the soil layer up to $30 \mathrm{~cm}$ were sampled, in the period October 2016-April 2017, in varying weather conditions. The analyzed soil sample was the average of ten samples obtained from each research point [7]. In the collected material were analyzed the followings:

- $\quad$ particle size distribution by laser diffraction method using Mastersizer 3000

- $\mathrm{pH}$ in $1 \mathrm{M}_{\mathrm{KCl}}$ with potentiometric method - by using a Mettler Toledo $\mathrm{pH}$ meter

- $\quad$ organic carbon by the Tiurin method

- $\quad$ sorption, iodine number determination [8]

- content of selected heavy metals $\mathrm{Cd}, \mathrm{Cu}, \mathrm{Pb}, \mathrm{Zn}, \mathrm{Ni}$, - determined by the BCR method (Community Bureau of Reference) and the ICP-AES technique

For the obtained results, the arithmetic mean, median, standard deviation were calculated. The size of the linear relationship between the tested parameters was determined. The statistical analysis of the results was carried out in Microsoft Excel 2010. 


\section{Results and discussion}

The soils of the studied areas were characterized by a varied granulometric composition of the sand fraction, from very thick $(1000 \mu \mathrm{m}-2000 \mu \mathrm{m})$ to very fine $(2 \mu \mathrm{m}-50 \mu \mathrm{m})$. In the tested soil samples no clay fraction was isolated (particles smaller than $2 \mu \mathrm{m}$ ). The largest percentage share was recorded for particles with a diameter between $250 \mu \mathrm{m}$ and $500 \mu \mathrm{m}$. They constituted from $27 \%$ to $36 \%$, slightly lower grain contents were noted for the $500 \mu \mathrm{m}-1000 \mu \mathrm{m}$ fraction, ranging from $22 \%$ to $28 \%$. For particles below $500 \mu \mathrm{m}$, this share was on the level from $11.5 \%$ to $25 \%$. Particles with a diameter from $50 \mu \mathrm{m}$ to $100 \mu \mathrm{m}$ accounted for $8.8 \%$, and grains from the interval $2 \mu \mathrm{m}-50 \mu \mathrm{m} 10.4 \%$ (Fig. 1). A characteristic feature of the studied soils is the absence of powdery fractions, grains $<2 \mu \mathrm{m}$ do not occur. Considering the distribution of soils according to the grain size of the sand fraction, they belong to the category of coarse materials. In relation to the entire sand fraction, the share of very coarse and coarse sand is an average of $36.7 \%$ with anindication of coarse sand. The share of medium sand is at the level of $35.9 \%$, fine and very fine sand $27.4 \%$ (Table 2).

Table 1. Locations of sampling and mean values for each point of: $\mathrm{pH}$ and organic carbon, iodine value in the soil samples tested.

\begin{tabular}{|c|c|c|c|c|c|}
\hline Sampling location & $\begin{array}{l}\text { Sample } \\
\text { no }\end{array}$ & $\begin{array}{l}\text { Form of } \\
\text { land use }\end{array}$ & $\begin{array}{l}\text { pH } \\
{[-]}\end{array}$ & $\begin{array}{l}\text { Corg } \\
{[\%]}\end{array}$ & $\begin{array}{c}\text { Iodine } \\
\text { value (IV) } \\
\text { [mg / g } \\
\text { d.m.] }\end{array}$ \\
\hline & & \multicolumn{4}{|c|}{ Mean values } \\
\hline Warszawska St., multi-family building & 1 & \multirow{2}{*}{$\begin{array}{c}\text { recreational } \\
\text { and } \\
\text { decorative }\end{array}$} & 8.05 & 1.95 & 101 \\
\hline Warszawska St., Lukol fuel station & 2 & & 8.05 & 2.58 & 95 \\
\hline $\begin{array}{c}\text { Warszawska St., ventilation } \\
\text { air launcher }\end{array}$ & 3 & \multirow{3}{*}{$\begin{array}{l}\text { recreation } \\
\text { and sports }\end{array}$} & 7.98 & 1.37 & 71 \\
\hline Tysiaclecia PP Ave., volleyball field & 5 & & 8.34 & 1.13 & 55 \\
\hline Solidarnosci Ave., garbage pavilion & 6 & & 7.99 & 1.48 & 61 \\
\hline Tysiaclecia PP Ave., car park & 4 & \multirow{2}{*}{ car parks } & 8.04 & 0.56 & 52 \\
\hline Solidarnosci Ave., tenis courts & 7 & & 7.06 & 0.69 & 57 \\
\hline
\end{tabular}

Table 2. The subfraction percentage of coarse, medium and fine sand in relation to the whole sand fraction for the analyzed soils.

\begin{tabular}{|c|c|c|c|c|c|c|c|c|}
\hline \multirow{2}{*}{$\begin{array}{c}\text { Subfraction } \\
{[\boldsymbol{\mu m}]}\end{array}$} & \multicolumn{7}{|c|}{ The subfraction percentage in the whole sand fraction [\%] } \\
\cline { 2 - 9 } & 1 & 2 & 3 & 4 & 5 & 6 & 7 & Average \\
\hline $\begin{array}{c}\text { The very coarse and coarse } \\
\text { sand 2000:500 }\end{array}$ & 42 & 34 & 25 & 35 & 29 & 37 & 55 & 36.7 \\
\hline Medium sand 500:250 & 34 & 37 & 36 & 38 & 39 & 38 & 29 & 35.8 \\
\hline $\begin{array}{c}\text { Fine and very fine sand } \\
\text { 250:50 }\end{array}$ & 24 & 29 & 38 & 27 & 32 & 26 & 16 & 27.5 \\
\hline
\end{tabular}

The research on soil $\mathrm{pH}$, measured in $1 \mathrm{M} \mathrm{KCl}$ [PN-ISO 10390: 1997], was characterized by $\mathrm{pH}$ in the range of $7.00-8.41$; the average $\mathrm{pH}$ values were at $\mathrm{pH} 7.07$ to $\mathrm{pH} 8.34$ indicating neutral and slightly alkaline $\mathrm{pH}$ of average correlation of $\mathrm{pH}$ with organic carbon content, linear correlation coefficient $\mathrm{R}^{2}=0.0997$ (Table 1, Fig. 2 and Fig. 3). 


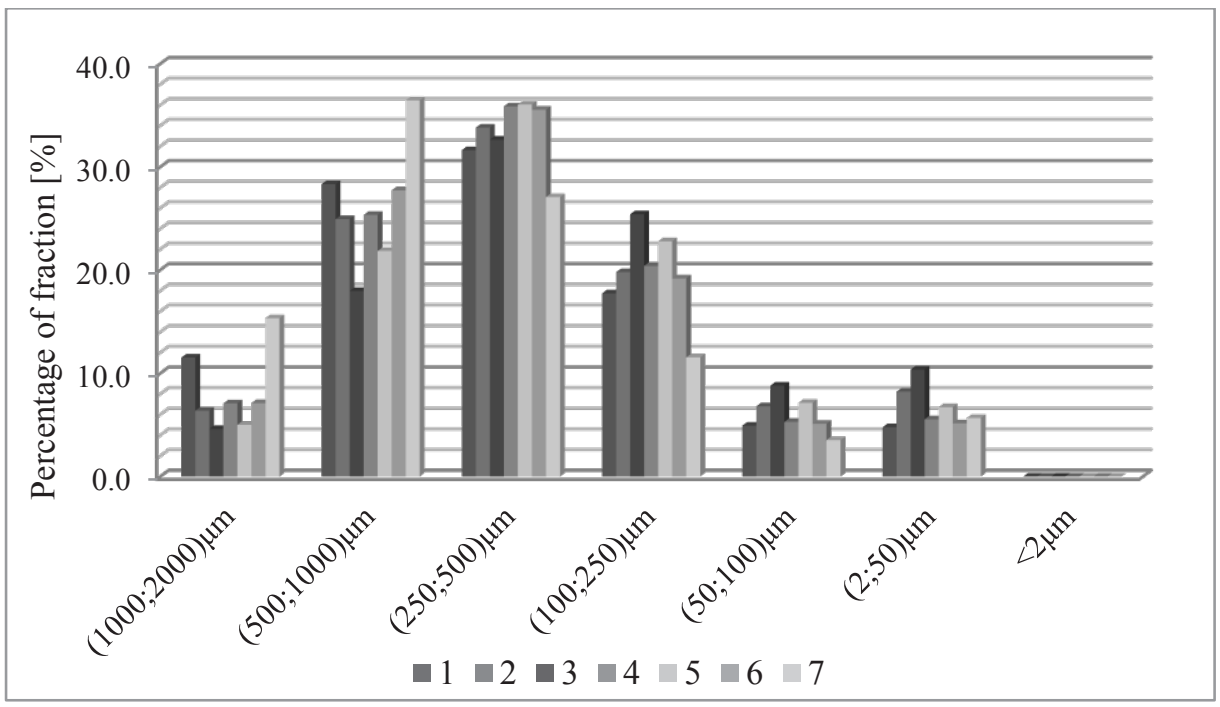

Fig. 1. Percentage of analyzed soil fractions.

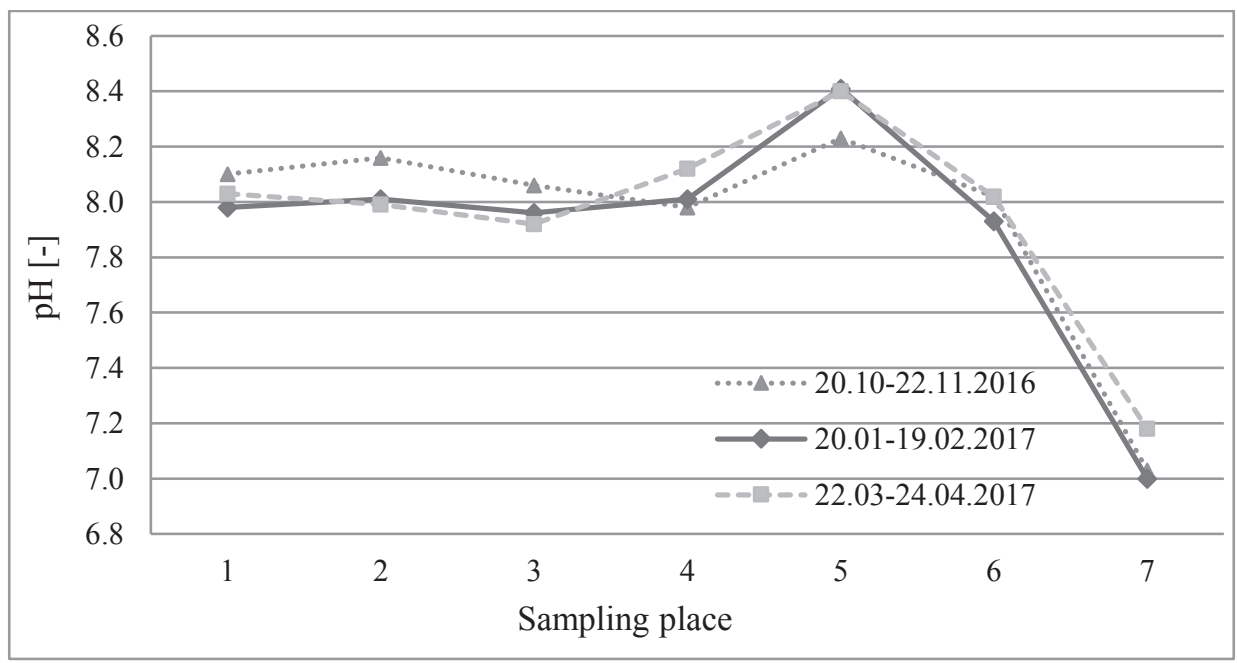

Fig. 2. The dependence of $\mathrm{pH}$ of the tested soil on the place of sampling.

The organic carbon content in the samples tested was significantly diversified (Table 1). The largest percentage content of organic matter occurred in the area between the Lukoil station and single-family housing (point 2). Residents of single-family houses developed a "unused" area for a composer and their own gardening needs. In autumn, the content of organic carbon in soil was $3.66 \%$. The smallest percentage of organic carbon content, and thus humus, occurs in the soil in the car park $0.56 \%$ (point 4 ) and at tennis courts $0.69 \%$ (point 7), which are located at the intersection of three very busy streets (Table 1).

By high sorption is characterized the soil used for decoration by the residents of the studied area (point 1), also the soil from managed plant residues (point 2) and at a waste shed (point 6) and a ventilation outlet, where the rocky-stony substrate has been fertilized with arable land (point 3). Correlation of organic carbon content and soil sorption expressed in iodine value $[I V]$ is at the high level of $\mathrm{R}^{2}=0.4247$, but organic carbon and $\mathrm{pH}$ at the average level (Fig. 3). Linear correlation coefficients evidence 
of the local shaping of the properties of the soil used by fertilizing with humus soil, but not of necessary even planting out. Linear correlation coefficients indicate the local shaping of the properties of the soil by fertilizing with humus soil, but not necessary evenly distributing it.

Table 3. Statistical parameters for the overall content of selected metals in studied soils.

\begin{tabular}{|c|c|c|c|c|}
\hline \multirow{2}{*}{ Parameters } & $\mathbf{P b}$ & $\mathbf{C u}$ & $\mathbf{Z n}$ & $\mathbf{N i}$ \\
\cline { 2 - 5 } & \multicolumn{4}{|c|}{$\left[\mathrm{mg} \cdot \mathrm{kg}^{-1} \mathrm{~d} . \mathrm{m}.\right]$} \\
\hline Maximum & 105.6 & 48.3 & 7.3 & 402.4 \\
\hline Minimum & 84.1 & 48.0 & 6.9 & 270.9 \\
\hline Average & 95.9 & 48.1 & 7.1 & 328.9 \\
\hline Median & 98.1 & 48.1 & 7.3 & 313.4 \\
\hline Standard deviation & 10.9 & 0.2 & 0.2 & 67.1 \\
\hline $\begin{array}{c}\text { The average content for the FI } \\
\text { fraction in the BCR analysis }\end{array}$ & 26.4 & 11.9 & 1.8 & 81.8 \\
\hline $\begin{array}{c}\text { Permissible content of selected } \\
\text { metals in the soil [9] }\end{array}$ & 200 & 200 & 500 & 150 \\
\hline
\end{tabular}

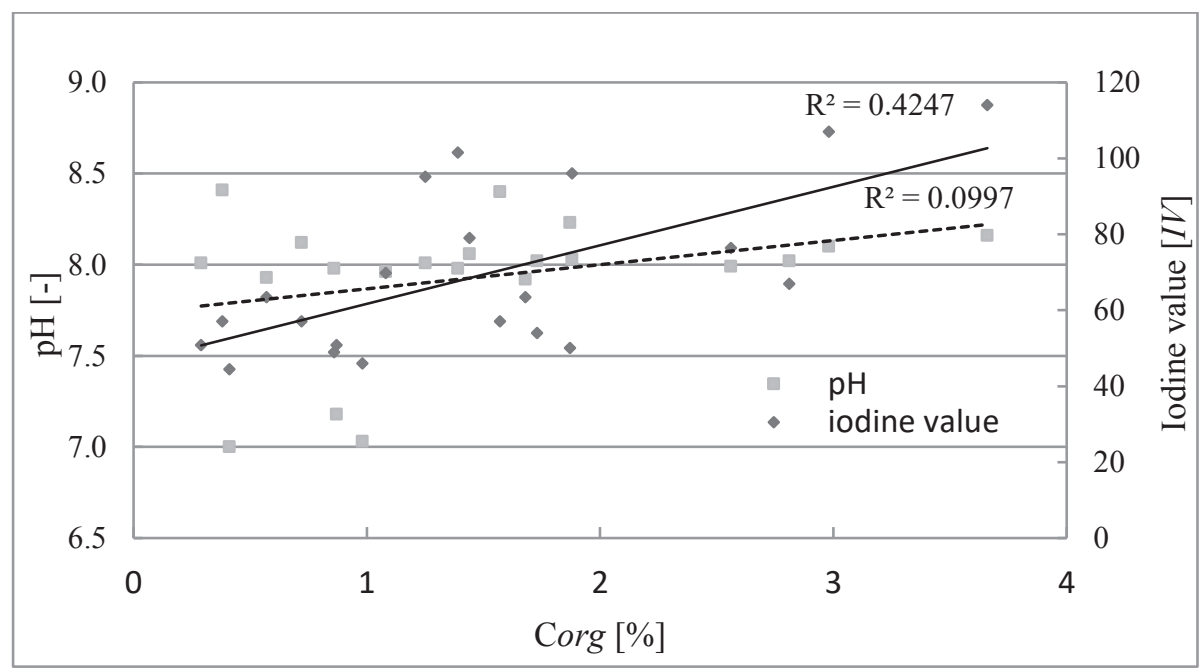

Fig. 3. The dependence of $\mathrm{pH}$ and iodine value $(\mathrm{IV}) \mathrm{mg} / \mathrm{kg} \mathrm{d.m}$. on the percentage of organic carbon $\left(\mathrm{C}_{\text {org }}\right)$ in the soil.

Determination of the total metal content in the soil is not a sufficient factor, because the bioaccumulation of metals depends on the content of the mobile fraction. For anthropogenic soil samples, the best results are obtained using a four-step procedure developed by the European Community Bureau of Reference - BCR. The study results are presented for four heavy metals: lead, nickel, copper and zinc, which were conducted in the extracts of the fraction: FI (exchangeable, easily soluble in acidic medium), FII (reducible-oxide, bound to $\mathrm{Fe}$ and $\mathrm{Mn}$ oxides), FIII (oxidizable - organic bound to sulphides) and FIV (residual) in $\mathrm{mg} / \mathrm{kg}$ d.m. [9]. The content of $\mathrm{Ni}, \mathrm{Pb}, \mathrm{Cu}$ and $\mathrm{Zn}$ metals in individual fractions was determined by the ICP-AES method. 


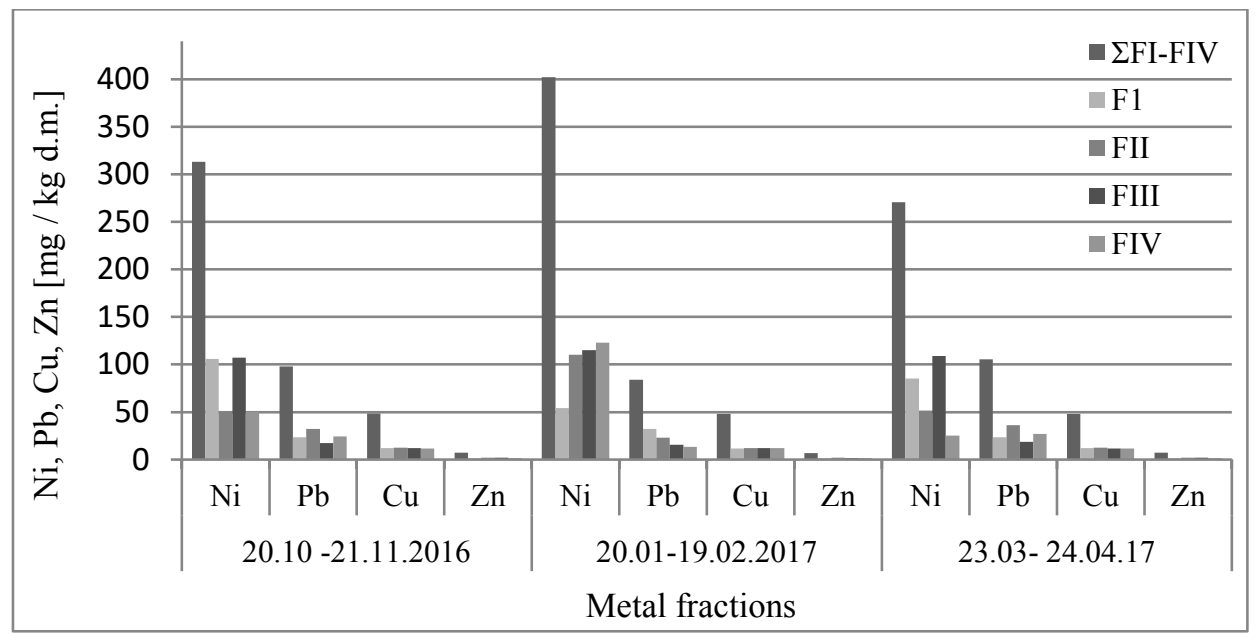

Fig. 4. The dependence of total metals content and individual fractions of BCR sequential analysis for: nickel $\mathrm{Ni}$, lead $\mathrm{Pb}$, copper $\mathrm{Cu}$, zinc $\mathrm{Zn}$ in collected soil samples during the research period.

The total contents of the determined heavy metals were placing in ranges as follows: for $\mathrm{Ni}$ (270.92-402.43 mg/kg d.m); Pb (84.05-105.63 mg/kg d.m.); Cu (47.89-48.32 mg/kg d.m.); Zn (6.94-7.32 mg/kg d.m.).

The metals of the exchangeable fraction FI by the changes in the ionic composition of water can get into solution and then become dangerous to plants and people. For the fraction FI (exchangeable, carbonate) $\mathrm{Ni}$ : $54.18-105.75 \mathrm{mg} / \mathrm{kg}$ d.m.; $\mathrm{Pb}$ : 23.50-32.06 mg/kg d.m.; Cu 11.75-12.05 mg/kg d.m.; Zn 1.50-1.75 mg/kg d.m. (Table 4). Statistical parameters for the total content of selected metals and FI fraction are given in Table 3.

Table 4. Metal fractions - by BCR method.

\begin{tabular}{|c|c|c|c|c|c|}
\hline \multirow{2}{*}{ Sampling date } & \multirow{2}{*}{ Metal } & \multicolumn{4}{|c|}{ Metal fractions [mg / kg d.m.] } \\
\cline { 2 - 6 } & $\mathrm{Ni}$ & 105.75 & 50.44 & 107.00 & 50.25 \\
\hline \multirow{3}{*}{$20.10-22.11 .2016$} & $\mathrm{~Pb}$ & 23.50 & 32.44 & 17.56 & 24.56 \\
\cline { 2 - 6 } & $\mathrm{Cu}$ & 12.06 & 12.56 & 11.89 & 11.81 \\
\cline { 2 - 6 } & $\mathrm{Zn}$ & 1.63 & 2.00 & 2.19 & 1.50 \\
\hline \multirow{3}{*}{$20.01-19.02 .2017$} & $\mathrm{Ni}$ & 54.18 & 110.31 & 115.13 & 122.81 \\
\cline { 2 - 7 } & $\mathrm{Pb}$ & 32.06 & 23.19 & 15.56 & 13.24 \\
\cline { 2 - 6 } & $\mathrm{Cu}$ & 11.75 & 12.19 & 11.89 & 12.06 \\
\cline { 2 - 7 } & $\mathrm{Zn}$ & 1.50 & 2.13 & 1.56 & 1.75 \\
\hline \multirow{3}{*}{$22.03-24.04 .2017$} & $\mathrm{Ni}$ & 85.31 & 51.43 & 109.12 & 25.06 \\
\cline { 2 - 7 } & $\mathrm{Pb}$ & 23.56 & 36.31 & 18.63 & 27.13 \\
\cline { 2 - 6 } & $\mathrm{Cu}$ & 12.00 & 12.50 & 11.81 & 11.75 \\
\cline { 2 - 6 } & $\mathrm{Zn}$ & 1.75 & 1.94 & 2.06 & 1.56 \\
\hline
\end{tabular}


The content of metals of the reducible fraction FII, fraction containing sulphides and organic matter FIII and residual FIV are presented in Table 4. The obtained contents of nickel, lead, copper and zinc in the fraction FI of the BCR sequential analysis have not exceeded the permissible concentrations, for communication areas specified in the ordinance of the Minister of the Environment [10].

The exception was the total nickel content. In the determined soil samples the total nickel concentration exceeded the admissible values determined by the standard [10] 2 times in autumn and in spring, 2.5 times in winter (Table 3). Similar results were recorded in a meadow soils located next to the arterial roads [1].

The average share (\%) of nickel, lead, copper and zinc in the sequentially separated fractions, in relation to the total content is shown in the series of decreasing values: for $\mathrm{Ni}$ : FIII (33.60) > FI (24.9) > F2 (21.5) > FIV (20.1); for Pb: FII (32.0) > FI (27.5) > FIV (22.6) $>$ FIII (18.0); for Cu: FII (25.8) > FI (24.8) > FIII (24.7) > FIV (24.7) and for Zn: FII (28.1) $>$ FIII (25.7) > FI (22.6) > FIV (17.1) (Fig.5). The varied, to a small extent, percentage content of the metal fraction in the research areas is the result of a similar location and similar use (Table 1, Fig. 5).

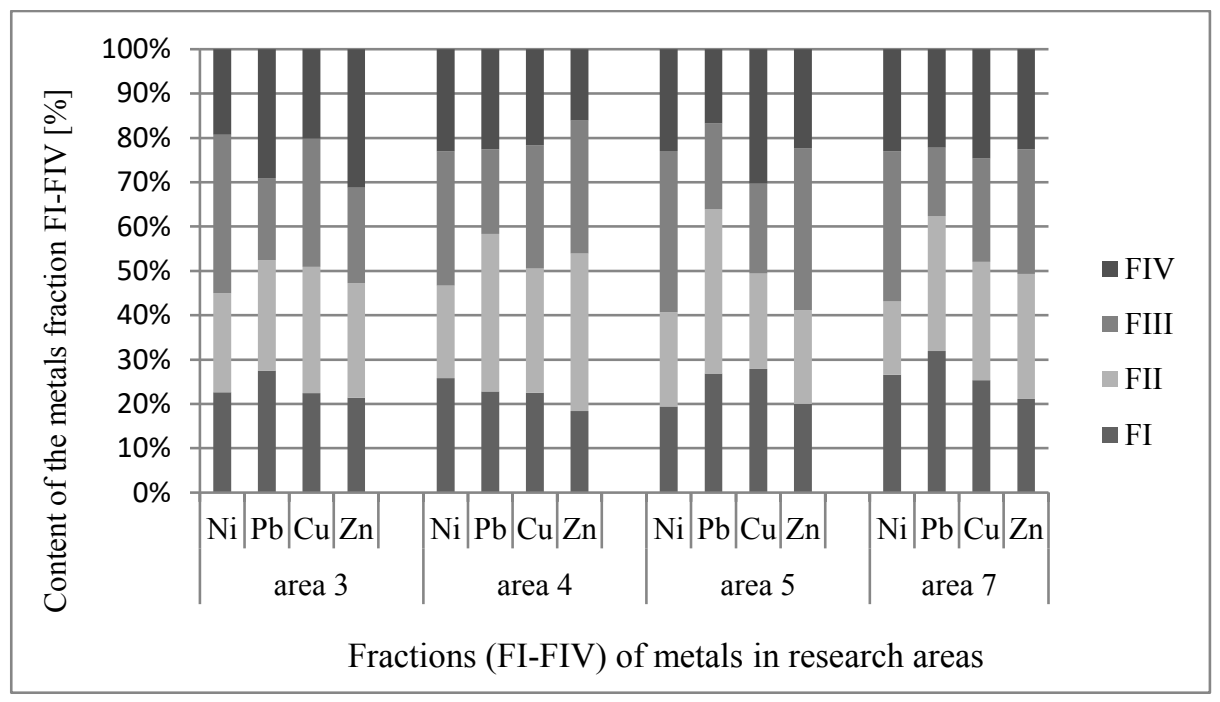

Fig. 5. The dependency of percentage [\%] share of the fraction FI-FIV of nickel, lead, copper and zinc from the place where the soil sampling took place, during the research period.

\section{Summary}

The anthropogenic soil in the studied areas is neutral and slightly alkaline. There is a high correlation between the content of organic carbon and the sorption expressed with a iodine value. The content of organic matter in the studied soils is in average at the level of $1.39 \%$, and in the studied areas, and additionally used by residents, $2.58 \%$. This proves the impact of residents interference in improving soil quality and its management [11]. The results of sequential extraction confirm the thesis that the share of heavy metals in soil fractions depends primarily on the type of metal and properties of soil and the way of how the soil is used [9]. Increased total nickel content up to $402.43 \mathrm{mg} / \mathrm{kg}$ in winter indicates that remedial actions have been taken to limit the concentration of heavy metals in the studied soils of the campus area of the Kielce University of Technology. Nickel belongs 
to the elements of the medium degree of risk, but long-term effects can lead to chronic poisoning of the body and mutagenic changes [12].

\section{Conclusions}

The results of the conducted research allow to formulate the following conclusions:

- The content of heavy metals (nickel, lead, copper, nickel) in the fractions of sequential analysis in the studied area does not exceed the permissible concentrations important for anthropogenic soils of communication areas.

- The exceeded total nickel content indicates to take actions reducing the increased concentration.

- The highest content among the analyzed metals have nickel, the lowest zinc.

- The analysis of results obtained from soil studies allows to conclude that recreational use of the campus is safe for the health of users, but prolonged exposure to the site may pose a health risk.

- Monitoring and "green" land development are recommended.

\section{References}

1. A. Chrzan, G. Formicki, Proceedings of ECOpole 6, 2 (2012)

2. R. Śpiewak, J. Piętowska, Alergologia i Immunologia, 3 ( 2006)

3. Ch. Luo, R. Yang, Y. Wang, Y. Li, G. Zhang, X. Li, Sci. Total Environ. 431 (2012)

4. A. Duda-Chodak, U. Błaszczyk, J. Elementol. 13, 4 (2008)

5. M.Widłak, R.Stoińska, M.Dańczuk, A.Widłak, Structure and Environment, 4, 9 (2017)

6. J. Gawdzik, Mobilność wybranych metali ciężkich $w$ osadach ściekowych (Monographs, studies, hearings, Kielce University of Technology, M44, 2013)

7. A. Świercz, E. Sykała, Ochrona Środowiska i Zasobów Naturalnych, 40 (2009)

8. PN-83C-97555.04 - Węgle aktywne. Metodyka Badań. Oznaczenie liczby adsorpcji jodu. (Activated carbons. Research mrthodology. Determination of Adsorption Value of iodine)

9. B.L. Larner, A.J. Sean, A.T. Townsend, Water Environ. Res. 71 (1999)

10. Rozporządzenie Ministra Środowiska z dnia 5 września 2016 r. w sprawie sposobu prowadzenia oceny zanieczyszczenia powierzchni ziemi, (Ordinance of the Minister of the Environment of 5 September 2016 on how to conduct an assessment of land surface pollution, Dz.U. 2016 nr 0 poz.1395, in Poland)

11. M. Sitarski, Człowiek i Środowisko, 32 (2008)

12. S. Drzymała, W. Spychalski, Roczniki Gleboznawcze, 2 (2011) 